\title{
BUILDING A MODEL OF SOCIAL AND PSHYCHOLOGICAL ADAPTATION
}

\author{
Venelin Terziev \\ Corresponding Member of the Russian Academy of Natural History, Moscow, Russia, Prof. D.Sc. \\ (Ec.), D.Sc. (National Security), D.Sc. (Social Activities), Ph.D., National Military University, Veliko \\ Tarnovo, Bulgaria; University of Rousse, Rousse, Bulgaria, terziev@skmat.com
}

\begin{abstract}
The paper presents a model for social and psychological assistance to militaries discharged of service and the members of their families through the example of Bulgaria which has the potential to be a basis for the creation of an adaptive program and setting up criteria for efficiency in it. The model implies a main recommendation, namely - gaining of key competences adequate to the civil socium and labor market requirements which should be extended in further research. The model is based on the process of the social adaptation - its essence, peculiarities and affecting factors, as well as key elements and mechanisms.
\end{abstract}

Keywords: social adaptation, model, assistance.

\section{MAIN CONSIDERATIONS IN THE MODEL CREATION}

Starting basis for the creation of a model for socio-psychological assistance of servicemen discharged from military service and members of their families, is the fact that the process of social adaptation takes place at the following three levels:

Society (macro-environment) level, at which the characteristics of social policy in the sphere of life activity and its directing in the required direction, are defined;

Social group (micro-environment) level, elucidating the causes of conflict in the system „individual-social group", and where assistance is given for resolving this problem;

The individual himself (intra-personal adaptation), while at this level efforts are made for the purpose of formation of self-consciousness, i.e. provision of psychological help. Account should be taken that the mechanisms for social adaptation of servicemen, discharged from military service, are not unique. The mere adjustment period is considered as a multistep process of forming competence, consisting of four phases.

At that, it should be emphasized that the change of self-consciousness in the process of acquiring competence occurs in a spiral: 
- Sustainable, defined, well connected inner world of unconscious competence;

- Super stable, polarized, rigid world of unconscious competence;

- Super unstable, fickle world of conscious incompetence;

- Stable, flexible world of conscious competence;

- Balanced extended version of the world of unconscious competence.

Solving the problems at each level of the process of social adaptation, passing through the respective phases of the formation of competence (unconscious competence, unconscious incompetence, conscious competence and conscious incompetence) is determined by the dynamic changes in the social environment. More specifically, the main determinants are the mostly negative effects of the macro- and microenvironment, of the interpersonal communication.

Moreover, the acquiring of competence, requires to define the boundaries of the transition between phases and to ensure conscious transition between all levels of the process. This means that during the different phases of competence, different intellectual and emotional efforts from the ones who are adapting, and skills of selection and use of appropriate techniques by the adapters, are required.

And since change of consciousness in the process of acquiring competence occurs in a spiral, it is necessary to review the adaptation cycle at a deeper level.

In the ordinary course, the serviceman is well aware of the conditions of his/her professional and life being. He easily predicts the consequences of his/her actions and tasks. The notice of the discharge from military service makes him/her predict his/her life outside the army in conditions of information deficit. An inevitable concern arises, result of which sometimes is a tendency of aggressive behavior, where hostility and instrumental aggression should be distinguished.

Hostility is a manifestation of attempts to obtain "non-confirmed forecast" by violent means. An example of this is the desire of the discharged from military service servicemen to receive the same financial security as in the army, but the offered to him/her options are too often "cheaper". His/her reaction may represent hostility (to those who discharged him/her from service in the army, those who offer lower salary, etc.). Harming people whom he considers guilty for his/her failures becomes an end in itself of his/her behavior.

Instrumental aggression is causing harm in order to achieve other goals (constructive in point of view of the individual). It is often accompanied by active social behavior for protection of ones rights and dignity, i.e. it is more constructive than hostility. Instrumental aggression occurs in all phases of competence, as opposed to hostile behavior, which is a clear indication of the stage of unconscious incompetence.

Studying the depressive tendency of behavior, we can distinguish depression, which occurs in denial of problems (attempt not to be noticed) and depression, in which exaggerating the problems occurs. In both cases, the individual tries to avoid constructive consideration of the emerging before him/her tasks. As a rule, depression of denial of problems occurs during the phase of unconscious incompetence. Like hostility, it is dictated by the desire to get the non-confirmed forecast. The depression of exaggerating the problems, characteristic of the phase of conscious incompetence, is related to "limiting beliefs" like "this cannot be overcome", "it is possible for others, but it is not possible for me", and so on.

Studies show that unproductive hostility occurs most often when people suppose that frustrating effects are manifestations of someone's ill will, and not the result of a force majeure. Depression of exaggerating the problems occurs most often in those who are poorly informed about the possible ways to solve their problems, who are consumed by increased responsibility for the fate of their loved ones, and suppose that such a thing could happen only with them and no one else. This fact, more than ever necessitates prevention activities for preparing of the servicemen, discharged from military service, for the complexities of the adaptation period.

Reduction of the hostile and depressive tendencies can be helped by preliminary work, during which the reasons for discharge from military service (as a consequence of objective processes in the society and the army) are explained in detail and ways out of this situation are offered.

Of course, such prevention activities should be carried out by specially trained professionals (military and social workers, psychologists) and volunteers (already successfully adapted military reservists and members of their families).

When the transition to the stage of conscious incompetence goes beneficially, the serviceman realizes that he is not yet fully ready for civilian life, but he looks to the future with reasonable optimism and is ready to 
acquire new skills and knowledge. In this case, the task of social workers and psychologists-consultants is to assist the serviceman, passing in the reserve and the members of his/her family, in the course of adaptation to the new conditions of life and work. Here firstly comes out the qualification for new jobs and requalification, as well as provision of information about civil rights and social guarantees. But the most important in the work of the professional consultant is helping the client in creating personal planning and a positive image of his/her individual „l”.

It should be noted that at the present stage there is propensity to external and internal conflicts, search (formation) of a new circle and new ways of communication (communication partners). The latter conflicts with the requirements of the environment, and the new ones has not yet been formed. In this case it is necessary the consultant to train the client on effective communication. Internal conflicts are driven by "conflict of values". Adoption of new values, coordination of old and new experiences, and creating a picture of the world that meets the requirements of adaptation and at the same time would not contradict the fundamental values of the individual, is a non-trivial task that must jointly be solved by those who assist the process of adaptation and the adapting individual at the given stage. Advisable for this purpose, is the use of specialized techniques, designed to differentiate the behavior from the intentions, and the behavior from the situation, in which it is realized, as well as the integration of the values, carried out by extending the experience and finding a compromise between the conflicting beliefs.

Only when the discharged from military service serviceman takes the necessary decisions, adopts new behaviors and creates a new full picture of the world, then he can proceed with the realization of his/her plan. In order to avoid excess optimism of psychologists and social workers, they need to reckon with the fact that the servicemen passing in the reserve, in the course of adaptation to civil life, confront with a variety of problems: psychological stress, need for requalification, complexities in vocational rehabilitation, life difficulties and family discord.

Moreover, it should be remembered that it is impossible to adapt to life once and for all. Acting under the new conditions, the serviceman, now retired, and the members of his family are inevitably confronted with the need to review more than once already made decisions, to get used to new areas of activity and relationships, to gather information, to choose alternatives and estimate resources. In the big adaptive cycle, small, similar in structure tasks are solved. It is important to correctly assess one's own strengths and be able to psychologically maintain himself alone. Then, only in extreme conditions there is a need for social and psychological assistance.

It is appropriate to note that the complete adaptation of the discharged from military service servicemen and the members of their families to the conditions of civil life, is long enough and can last from one to three years.

In organizational terms, the most successful to work with servicemen discharged from the army and members of their families, is the model for "psychological-medical-social assistance”.

Such model for socio-psychological assistance should include the following three types of assistance that are at the same time also conditions for its provision: primary, skilled and specialized.

\section{FORMS OF ASSISTANCE}

Ideally, primary assistance should be provided in the military units by specially trained professionals (paraspecialists) among servicemen, by social protection workers and their volunteer associates. The task of the psychologists and the social workers from the centers is limited to methodological assurance of sociopsychological training of servicemen for discharge from the army and assistance in preparing paraspecialists for this activity.

Main form of primary assistance is the organization of work groups for social and psychological assistance, in which servicemen and members of their families, in specially created conditions in artificial micro-socium (where are collected individuals with similar problems) solve the arising before them psychological problems, related to their discharge from military service. Thus, the process of adaptation takes place in a more active and painless form for all group members. The involvement of professional psychologists-consultants within primary assistance is limited to supervision.

Skilled assistance that should be ensured by the centers for social and psychological adaptation of military personnel, discharged from military service, and members of their families, should be directed to:

- Conducting diagnostic activities on finding the persons prone to destructive strategies of adaptation and preventive work with them; 
- Socio-psychological assistance with various cases of disturbance of the adaptation process;

- Development of activities for personal planning, professional identification and personal growth;

- Counseling and group work for professional re-orientation towards retraining, assistance for vocational rehabilitation;

- Psychological counseling for servicemen, passing in the reserve, and members of their families;

- Development of methodologies for institutions and specialists, giving primary assistance, and paraspecialists; help.

- Supervision by para-specialists and methodological guidance at all stages of giving psychological

Attention should be paid to the fact that to skilled assistance also pertain the diagnosing and directing individuals with sharply expressed and neglected adaptation disorders (depression, alcoholism, deviant behavior, etc.) to specialized and rehabilitation institutions. This stage is characterized by continuity and coordination of efforts in all programs for socio-psychological adaptation and rehabilitation, while also working in a group and individually, as well as applying family counseling. Coordinating role at this stage should be played by the centers, because this is where information on programs for social and psychological assistance and retraining is accumulated and summarized, and experience between specialists is shared.

For the purpose of the operational performance of its functions, it is expedient to create a data bank in the center that includes adapted methodologies, latest publications on the issues of adaptation of servicemen, discharged from military service, social work, psychology, psychotherapy, as well as results from the monitoring studies, description of the summarized experience.

Specialized assistance is designed for those servicemen passing in the reserve and members of their families, with whom deviations in mental activities are found. This implies the creation of special conditions to support stationary or semistationary medical institutions, rehabilitation and health institutions, which should be based on the existing under the Ministry of Defense and the Ministry of Health, sanatoria, prophylactic centers, etc. As a rule, specialized care is organized under the authority of various administration departments. At that, the mechanisms of coordination and interaction with the other departments are built according to the system of administrative governance.

Psychological support and rehabilitation in providing primary, qualified and specialized assistance, are essential components of an effective social and psychological adaptation. In general, the work should be planned in several stages, for example, start one year before the discharge from the Military Forces and continue for 1.5-3 years after the discharge.

The first stage of measures for socio-psychological adaptation must take place at the places of service and of residence of the servicemen, and the members of their family, between 6 and 12 months prior to discharging them. The main objective of this stage is the preparation of the servicemen for the discharge from military service. It is important to provide information to the servicemen and to prepare them psychologically for both expecting possible difficulties (external and internal) during the transitional period, and for their behavior on the labor market.

The work should be carried out mainly in a group and belongs to the category of primary care. During this stage it is necessary to pay attention to the development of recommendations and methodological materials for conducting group informing seminars. They must be consistent with the need for formation in the minds of the attendants of a system of socially acceptable and realistic ways of setting and achieving goals in the new for them civil life, as well as to give them an objective and, if possible, complete picture of the existing social conditions in which they are going to live and work.

Such material should contain both pure informational blocks (statistics, observed social regularities) intended for cognitive absorption and bright concrete examples of successful adaptation of servicemen passing in the reserve, with a view of emotional absorption. Very useful in the case are the meetings with the military reservists who have already successfully adapted to the new conditions. The forms of work should vary: lecture type seminars should alternate with discussion seminars or research seminars. It is also desirable, with the help of tests or games, to check how well is the material "digested”. Along with the fully apparent control, this contributes to the increase of interest in what is happening in the group, to bringing competitive spirit in the sessions and to bringing the process of rehabilitation closer to the learning process. In these conditions the self-esteem of the servicemen is not hurt and they are not placed in a position of „psychologically disabled” in need of treatment and recovery. Organized in such way the socio-psychological 
work resembles the well-known military process of acquiring new knowledge, for which it is easier to find optimal strategies and internal resources, which exactly should be the goal of the ones developing programs and scenarios for the information seminars.

After completion of the first stage, the required level of loyalty to future changes in the lives of servicemen and members of their families should be reached. When they pass the stage of unconscious incompetence, they should continue to the phase of conscious incompetence. Diagnostic procedures are also carried out, according to the results of which, part of the contingent can be directed to rehabilitation in specialized institutions.

The second stage of rehabilitation activities is characterized in that the main work is focused on the acquisition of habits of personal planning and retraining. Timing of this stage must coincide with the activities on professional reorientation, requalification and solving social issues of the servicemen. With the help of paraspecialists, the psychologists consultants should conduct both individual and group sessions (seminars, trainings). The result should be achieving readiness for adaptation, which is accompanied by the transition from the phase of conscious incompetence to the conscious competence stage. This stage lasts less than a year. It is desirable not less than half of the activities to be conducted prior to the time of actual discharge. Experience shows that usually conducting such work in the military formations faces opposition.

The third stage of rehabilitation activities aims at social and psychological support of the adaptation process and can be called accompanying. It is characterized by the combination of group and individual working methods. Groups should serve as psychological support and exchange of experience, and individual consultations are aimed at correction of situational difficulties. This stage can last a year and a half to three years after discharge. After its completion level of adaptation must be achieved, in which occurs the transition from conscious to unconscious competence of the relatively new social and professional environment.

\section{BASICS OF SOCIAL AND PSYCHOLOGICAL SUPPORT}

In our opinion, the forms and methods of social and psychological support should be selected depending on the specific psychological problems arising in the process of adaptation of the discharged from military service servicemen to civil life. In turn, the forms and methods of rehabilitation should be depending on the particular psychological problems of adapting to civil life in one or another period(Terziev, 2017; Terziev, 2017a, pp.1375-1399; Terziev, 2017b, pp.1362-1377; Terziev, 2017c, pp.1378-1392; Terziev, 2017d, pp.1352-1361; Terziev, 2017e, pp.914 - 922; Terziev, 2017f, pp. 923 - 935; Terziev, 2017g, pp.49-59; 9.

Terziev, 2017h, pp.452-458; Terziev, 2017i, pp.786-796; Terziev, 2017j, pp. 997-1024; Terziev, Bogdanov, Madanski, Stefanov, 2017k, pp.85-97; Banabakova, Georgiev, 2017l, pp. 46-51; Banabakova, Georgiev, 2017m, pp. 462-467; Banabakova, Georgiev, 2017n, pp. 84-99; Banabakova, Georgiev, 2017o, pp. 468-483; Terziev, Madanski, Georgiev, 2017p, pp. 923-927; Terziev, Madanski, Georgiev, 2017q, pp. 1051-1055; Terziev, Nichev, Stoyanov, Georgiev, 2017r, pp. 888-892; Banabakova, Georgiev, 2017s, pp. 37-47).

On the grounds of the proposed model it is very important in the stage of qualified assistance to be defined the areas of life activity, the events that are evaluated by soldiers passing in the reserve and their families as the most severe and psycho-traumatic. In parallel, diagnostics of their strategies for resolving such situations should be carried out.

It should be taken into account that the availability of the information necessary for socio-psychological problems and the internal resources to deal with them, as well as the individual experience in dealing with difficulties, are the foundation of organizing and conductingbetter targeted and effective rehabilitation activities.

Highlighting of non-constructive and maladaptive ways of reacting to problems, gives the direction of the next psycho-correctional work to master through more efficient and optimal for a given situation strategies for coping with life's difficulties, including related to the changes in the social and professional status of the discharged from military service servicemen and members of their families, adaptation to civil life.

Basic principles of organization of social and psychological adaptation to civil life should be:

- Maximum proximity to the needs of adapting individual;

- Urgent, as early as possible start of activities for provision of social and psychological assistance;

- Unity of psychosocial and physiological methods of influence (unity of rehabilitation and treatment);

- Step-By-Step implementation, consistency and continuity of adaptation measures. Influences of any 
kind, including psychosocial, should be realized in certain portions of gradual (step-by-step) transition from one action (effort, measure) to another, from one form of organization of assistance to another;

- Comprehensiveness (complexity) of the efforts.

The activities for provision of social and psychological assistanceshould be realized in the following areas: psychological, professional, family, education, leisure, in the public sphere:

- Individualization of social and psychological impact. Restoration of mental equilibrium and social selfesteem of servicemen passing in the reserve, should be conducted in accordance of the specifics of the individual, the mechanisms and dynamics of his/her condition;

- Compliance of the activities with the adaptation capabilities of the individual;

- Systematic control and timely correction of the adaptation program.

Naturally, the question arises for optimal results of the process and the criteria for success of the sociopsychological adaptation. The answer is extremely important for the specialists who should organize the activities of this process and provide social and psychological assistance to the servicemen, discharged from military service.

There are different approaches to determining the given criteria. As a general indicator of a successful process of socio-psychological adaptation, can be considered the mutual satisfaction of the individual and the social environment. The status of the individual, allowing the achievement of such a relationship with the socium, can be called social adaptability. Thus, the individual, without long internal and external conflicts, chooses his/her life path and makes decisions, conducts his/her activity in a productive way, satisfying his basic social needs, remains fully consistent with the role expectations to the reference group, realizes himself and reveals his/her creative potential.

On the basis of the presented model becomes possible the conditional differentiation of the following types of adaptability:

- Adaptability in the extra-personal socio-economic activity, where the individual acquires knowledge, skills and habits, become competent and achieves mastership; adaptability in the field of inter-personal relationships, where intimate, evocative relationships with other people, are established;

- Inter-Personal adaptability, where a consistent, harmonious "Self-concept” is formed, and spiritual well-being and psychological health are achieved.

Thus, proceeding from the nature of socio-psychological adaptation of servicemen, the following criteria can be determined, defining the degree of effectiveness (satisfaction) of the socio-psychological assistance in the adaptation process:

- Criterion for social adaptation, including competitiveness, self-confidence, successful vocational rehabilitation, promotion on the job, stable family relationships, a sufficient level of professional qualification for the successful work in a new profession;

- Criterion for socio-psychological comfort of relationships, determined by the degree of satisfaction with relations in the new social environment, the job, the salary, relations with other people;

- Criterion for positive self-evaluation, determined by the absence of internal psychological conflicts and the absence of psychological defenses, going beyond pathology.

\section{CONCLUSION}

Summarizing, the presented model for social and psychological assistance to servicemen, discharged from military service and members of their families, can serve as a basis for the creation of adaptive program for the studied category of adapting individuals, corresponding to the dynamic changes in the social environment and the criteria for efficiency. Since the social adaptation servicemen, discharged from military service is directly related to their adaptability to their new civil socium, it by itself suggests forming new knowledge, skills and abilities in them, adequate to the requirements of this socium. And that means the formation of key competencies, adequate civil to the civil socium, complying with the labor market, on the basis of which the necessary specific competencies to be further built. Put another way, on the basis of the presented model, further our research deepens in terms of creating a competence model for social adaptation of servicemen, discharged from military service (Terziev, Madanski, Georgiev, 2017t, pp. 748753; Terziev, Madanski, Georgiev, 2017u, pp. 743-747; Madanski, Georgiev, 2017v, pp. 4-13; Madanski, Georgiev, 2017w, pp. 43-51; Terziev, Dzhumalieva, 2016a, s.233-253; Terziev, 2014, s.176-183; Terziev, 
IJASOS- International E-Journal of Advances in Social Sciences, Vol. IV, Issue 12, December 2018

2014a, s.183-191; Terziev, 2014b, s.192-204; Terziev, 2014c, pp.194-201; Terziev, 2014d, s.201-210;

Terziev, 2014e, s.210-222).

\section{REFERENCE LIST}

Terziev, Venelin. (2017). Opportunities For Improving The Efficiency Of The Socialadaptation Of Servicemen Discharged From Military Service In Bulgaria. // Catalogue Of The Scientific, Educational And Methodical Literature Presented By Authors At The I-XXXIV All-Russian Book Exhibitions Held By Academy Of Natural History, Exposition On The Frankfurter Buchmesse 2017, XXVII, Moskow, Academy Of Natural History, 2017.

Terziev, Venelin. (2017a). Social Adaptation As A Social Process In The Adaptation Of Military Personnel. // Journal Of Economic Geography, International Health, Oxford University Press, 17, 2017, N 6(2), Pp.1375-1399, ISSN 1468-2702, Source Normalized Impact Per Paper (SNIP): 2.358, Scimago Journal Rank (SJR): 2.909.

Terziev, Venelin. (2017b). Insights Into Some Examples Of Triggering The Process Of Social Adaptation. // International Health, Oxford University Press, 9, 2017, N6 (2), Pp.1362-1377, ISSN 1876-3413, Source Normalized Impact Per Paper (SNIP): 0.721, Scimago Journal Rank (SJR): 0.835.

Terziev, Venelin. (2017c). Examples Of Modelling Social Adaptation Of Servicemen Discharged From Military Service. // International Health, Oxford University Press, 9, 2017, N 6 (2), Pp.1378-1392, ISSN 1876-3413, Source Normalized Impact Per Paper (SNIP): 0.721, Scimago Journal Rank (SJR): 0.835.

Terziev, Venelin. (2017d). Studying Different Aspects Of Social Adaptation. // International Health, Oxford University Press, 9, 2017, N6 (2), Pp.1352-1361, ISSN 1876-3413, Source Normalized Impact Per Paper (SNIP): 0.721, Scimago Journal Rank (SJR): 0.835.

Terziev, Venelin. (2017e). Social Adaptation And Socialization As Processes: Characteristics, Principles, Factors. // European Journal Of International Law, Oxford University Press, 28, 2017, N 4 (2), Pp.914 922, ISSN 0938-5428, Source Normalized Impact Per Paper (SNIP): 1.424, Scimago Journal Rank (SJR): 0.722.

Terziev, Venelin. (2017f). Factors Affecting The Process Of Social Adaptation. // European Journal Of International Law, Oxford University Press, 28, 2017, N 4 (2), Pp. 923 - 935, ISSN 0938-5428, Source Normalized Impact Per Paper (SNIP): 1.424, Scimago Journal Rank (SJR): 0.722.

Terziev, Venelin. (2017g). A New View On Social Adaptation Of The Military, Discharged From Military Service In Bulgaria. // IJASOS- International E-Journal Of Advances In Social Sciences, April 2017, 3, 2017, N 7, ISSN 2411-183X, Pp.49-59.

Terziev, Venelin. (2017h). Factors Affecting The Process Of Social Adaptation. // $3^{\text {rd }}$ International Conference On Advanced Research In Business And Social Sciences 2017 29th To $30^{\text {th }}$ March, 2017, 1, 2017, ISBN: 978-967-13620-2-0, Pp.452-458.

Terziev, Venelin. (2017i). A New View On Social Adaptation Of The Military, Discharged From Military Service In Bulgaria. // Intcess 2017, $4^{\text {th }}$ International Conference On Education And Social Sciences, 6-8 February, 2017 - Istanbul, Turkey, 2017, ISBN 978-605-64453-9-2, Pp.786-796.

Terziev, Venelin. (2017j). A New View On Social Adaptation Of The Military, Discharged From Military Service In Bulgaria. // Oxford Review Of Economic Policy, 33, 2017, N 4 (2), Pp. 997-1024, ISSN 0266-903X. Source Normalized Impact Per Paper (SNIP): 1.014 Scimago Journal Rank (SJR): 0.974 Impact Factor: 0.764 5-Yr Impact Factor: 1.629.

Terziev, V., Bogdanov, P., Madanski, V., Stefanov, S. (2017k). Approaches To Social Adaptation Of Servicemen Discharged Of Military Service. // Eight International Scientific Conference Knowledge Without Borders, 8-10 Април 2016 Г., Банско, България. International Journal Scientific Papers, 12, 2016, N 2, ISSN1857-92, Pp.85-97.

Banabakova, V., Georgiev, M. (2017l). Military Professional Forming Of The Cadets At Vasil Levski National Military University. // IJAEDU- International E-Journal Of Advances In Education, April 2018, Turkey, International Organization Center Of Academic Research, Www.Ocerints.Org, Istanbul, Turkey, 2018, Pp. 46-51, 4, 2018, N 10, E-ISSN: 2411-1821. 
IJASOS- International E-Journal of Advances in Social Sciences, Vol. IV, Issue 12, December 2018

Banabakova, V., Georgiev, M. (2017m). Military Professional Forming Of The Cadets At Vasil Levski National Military University. // Proceedings Of INTCESS2018- 5th International Conference On Education And Social Sciences 5-7 February 2018- Istanbul, Turkey, International Organization Center Of Academic Research, Www.Ocerints.Org, Istanbul, Turkey, 2018, Pp. 462-467, ISBN: 978605-82433-2-3.

Banabakova, V., Georgiev, M. (2017n). The Role Of The Balanced Scorecard As A Tool Of Strategic Management And Control. // IJAEDU- International E-Journal Of Advances In Education, April 2018, International Organization Center Of Academic Research, Www.Ocerints.Org, Istanbul, Turkey, 2018, Pp. 84-99, 4, 2018, N 10, E-ISSN: 2411-183X.

Banabakova, V., Georgiev, M. (20170). The Role Of The Balanced Scorecard As A Tool Of Strategic Management And Control. // Proceedings Of INTCESS2018-5th In-Ternational Conference On Education And Social Sciences 5-7 February 2018- Istanbul, Turkey, International Organization Center Of Academic Research, Www.Ocerints.Org, Istanbul, Turkey, 2018, Pp. 468-483, ISBN: 978605-82433-2-3.

Terziev, V., Madanski, V., Georgiev, M. (2017p). Offset Implementation Impact On Technology Transfer In Bulgaria. // IJAEDU- International E-Journal Of Advances In Education, International Organization Center Of Academic Research, Www.Ocerint.Org, 3, 2017, N 9, Pp. 923-927, E-ISSN: 2411-18.

Terziev, V., Madanski, V., Georgiev, M. (2017q). Offset As An Economic Operation And A Trade Practice. // IJAEDU- International E-Journal Of Advances In Education, International Organization Center Of Academic Research, Www.Ocerint.Org, 3, 2017, N 9, Pp. 1051-1055, E-ISSN: 2411-18.

Terziev, V., Nichev, N., Stoyanov, E., Georgiev, M. (2017r). A General Principle Of The Development Process Of Balanced Scorecards As An Instrument Of Control. // IJAEDU- International E-Journal Of Advances In Education, International Organization Center Of Academic Research, Www.Ocerint.Org, 3, 2017, N 9, Pp. 888-892, E-ISSN: 2411-18.

Banabakova, V., Georgiev, M. (2017s). Problems And Perspectives In Military Professional Education And Realization Of Cadets In Bulgaria. // Journal Of Innovations And Sustainability, Innovations And Sustainability Academy. 3, 2017, N 4, Pp. 37-47, ISSN 2367-8127 (CD-ROM), ISSN 2367-8151 (OnLine).

Terziev, V., Madanski, V., Georgiev, M. (2017t). Offset As An Economic Operation And A Trade Practice. // Proceedings Of ADVED 2017- 3rd International Conference On Advances In Education And Social Sciences 9-11 October 2017- Istanbul, Turkey. International Organization Center Of Academic Research, Www.Ocerint.Org, 2017, Pp. 748-753, ISBN: 978-605-82433-0-9.

Terziev, V., Madanski, V., Georgiev, M. (2017u). Offset Implementation Impact On Technology Transfer In Bulgaria. // Proceedings Of ADVED 2017- 3rd International Conference On Advances In Education And Social Sciences 9-11 October 2017- Istanbul, Turkey. International Organization Center Of Academic Research, Www.Ocerint.Org, 2017, Pp. 743-747, ISBN: 978-605-82433-0-9.

Madanski, V., Georgiev, M. (2017v). The Offset As A Specific Sort Of Economic Activity. // Scientific Journal «Economics And Finance». Academic Publishing House Of The Agricultural University, Priority Research Areas: Collection Of Scientific Articles, 2017, Pp. 4-13, ISBN 978-617-7214-53-2.

Madanski, V., Georgiev, M. (2017w). Study Of The Effect Of Offset Implementation On Technology Transfer In The Republic Of Bulgaria. // Scientific Journal «Economics And Finance». Academic Publishing House Of The Agricultural University, Priority Research Areas: Collection Of Scientific Articles, 2017, Pp. 43-51, ISBN 978-617-7214-53-2.

Terziev, V., Dzhumalieva, A. (2016a). Dostapnost Do Pazara Na Truda I Sotsialna Adaptatsiya Na Osvobodenite Ot Balgarskata Armiya Voennosluzheshti I Chlenovete Na Tehnite Semeystva. // XI Mezhdunarodnoy Nauchnoy Konferentsii „Innovatsii V Tehnologiyah I Obrazovanii", 18-19 Marta 2016 G., Kuzbasskiy Gosudarstvennayy Tehnicheskiy Universitet Im. T.F. Gorbacheva, Belovo, 4, 2016, ISBN 978-5-906888-04-4, S.233-253 (Терзиев, В., Джумалиева, А. Достъпност До Пазара На Труда И Социална Адаптация На Освободените От Българската Армия Военнослужещи И Членовете На Техните Семейства. // XI Международной Научной Конференции „Инновации В Технологиях И Образовании", 18-19 Марта 2016 Г., Кузбасский Государственный Технический Университет Им. Т.Ф. Горбачева, Белово, 4, 2016, ISBN 978-5-906888-04-4, С.233-253).

Terziev, Venelin. (2014). Possible Aspects Of Occupational And Psychological Adaptation Of The Military, Discharged From Military Service And Their Families To A New Activity Life Cycle. // 
Mezhdunarodnaya Nauchno-Prakticheskaya Konferentsiya „Nauka XXI Veka: Teoriya, Praktika, Perspektivay", 6 Iyunya 2014, Ufa, Rossiya, 2014, ISBN 978-5-906763-30-3, S.176-183 (Terziev, Venelin. Possible Aspects Of Occupational And Psychological Adaptation Of The Military, Discharged From Military Service And Their Families To A New Activity Life Cycle. // Международная НаучноПрактическая Конференция „Наука XXI Века: Теория, Практика, Перспективы”, 6 Июня 2014, Уфра, Россия, 2014, ISBN 978-5-906763-30-3, С.176-183).

Terziev, Venelin. (2014a). Realities Of Implementing The Social Adaptation Procees Of Military Personnel, Discharged Form Service In Bulgaria. // Mezhdunarodnaya Nauchno-Prakticheskaya Konferentsiya „Nauka XXI Veka: Teoriya, Praktika, Perspektivay”, 6 Iyunya 2014, Ufa, Rossiya, 2014, ISBN 978-5906763-30-3, S.183-191 (Terziev, Venelin. Realities Of Implementing The Social Adaptation Procees Of Military Personnel, Discharged Form Service In Bulgaria. // Международная НаучноПрактическая Конференция „Наука XXI Века: Теория, Практика, Перспективы”, 6 Июня 2014, Уфра, Россия, 2014, ISBN 978-5-906763-30-3, С.183-191).

Terziev, Venelin. (2014b). Bulgarian Experience In The Development Of Social Adaptation Of Military Personnel, Discharged From Military Service And Their Families. // Mezhdunarodnaya NauchnoPrakticheskaya Konferentsiya „Nauka XXI Veka: Teoriya, Praktika, Perspektivay”, 27 lyunya 2014, Ufa, Rossiya, 2014, ISBN 978-5-906763-30-3, S.192-204 (Terziev, Venelin. Bulgarian Experience In The Development Of Social Adaptation Of Military Personnel, Discharged From Military Service And Their Families. // Международная Научно-Практическая Конференция „Наука XXI Века: Теория, Практика, Перспективы”, 27 Июня 2014, Уфа, Россия, 2014, ISBN 978-5-906763-30-3, С.192-204).

Terziev, Venelin. (2014c). Possible Aspects Of Occupational And Psyhological Adaptation Of The Military, Discharged From Military Service And Their Families To A New Activity Life Cycle. // Международная Научно-Практическая Конференция: 27 Июня 2014, „Наука И Современность”, Уфа, Россия, 2014, ISBN 978-5-906763-48-8, Pp.194-201 (Terziev Venelin. Possible Aspects Of Occupational And Psyhological Adaptation Of The Military, Discharged From Military Service And Their Families To A New Activity Life Cycle. // Mezhdunarodnaya Nauchno-Prakticheskaya Konferentsiya: 27 lyunya 2014, „Nauka I Sovremennosty”, Ufa, Rossiya, 2014, ISBN 978-5-906763-48-8, Pp.194-201).

Terziev, Venelin. (2014d). Realities Of Implementing The Social Adaptation Process Of Military Personnel, Discharged From Service In Bulgaria. // Международная Научно-Практическая Конференция 27 Июня 2014, „Наука И Современность”, Уфра, Россия, 2014, ISBN 978-5-906763-48-8, С.201-210 (Terziev, Venelin. Realities Of Implementing The Social Adaptation Process Of Military Personnel, Discharged From Service In Bulgaria. // Международная Научно-Практическая Конференция 27 Июня 2014, „Наука И Современность”, Уфа, Россия, 2014, ISBN 978-5-906763-48-8, С.201-210).

Terziev, Venelin. (2014e). Bulgarian Experience In The Development Of Social Adaptation Of Military Personnel, Discharged From Military Service And Their Families. // Mezhdunarodnaya NauchnoPrakticheskaya Konferentsiya 27 Iyunya 2014, „Nauka I Sovremennosty”, Ufa, Rossiya, 2014, ISBN 978-5-906763-48-8, S.210-222 (Terziev, Venelin. Bulgarian Experience In The Development Of Social Adaptation Of Military Personnel, Discharged From Military Service And Their Families. // Международная Научно-Практическая Конференция 27 Июня 2014, „Наука И Современность”, Уфа, Россия, 2014, ISBN 978-5-906763-48-8, С.210-222). 